\title{
PENGARUH MODEL PEMBELAJARAN DIRECT INSTRUCTION BERBANTUAN VIDEO DAN KOMPETENSI PEDAGOGIK GURU TERHADAP HASIL BELAJAR RIAS KREATIF SISWA KELAS XI TATA KECANTIKAN KULIT SMK NEGERI 2 SINGARAJA
}

\author{
Ni Ketut Yuliana Dharmayani, I Nyoman Natajaya, Dewa Gede Hendra Divayana \\ Program Studi Administrasi Pendidikan, Program Pascasarjana \\ Universitas Pendidikan Ganesha \\ Singaraja, Indonesia \\ e-mail: \{yuliana.dharmayani, nyoman.natajaya, \\ hendra.divayana\}@pasca.undiksha.ac.id
}

\begin{abstract}
Abstrak
Penelitian ini bertujuan untuk mengetahui pengaruh model pembelajaran direct instruction berbantuan video dan kompetensi pedagogik guru terhadap hasil belajar rias kreatif siswa kelas XI Tata Kecantikan Kulit SMK Negeri 2 Singaraja. Penelitian ini adalah penelitian eksperimen dengan menggunakan rancangan penelitian semu dengan pola "The Posttest-Only Control Design" dengan besar populasi 71 orang, dan sampel 37 orang. Data dikumpulkan dengan tes. Analisis data dilakukan dengan Anakova. Hasil penelitian menunjukkan bahwa: 1) terdapat pengaruh yang signifikan model pembelajaran direct instruction berbantuan video terhadap hasil belajar rias kreatif siswa dengan siswa yang mengikuti model pembelajaran konvensional. Hasil belajar siswa dengan menggunakan model pembelajaran direct instruction berbantuan video lebih tinggi dari pada hasil belajar menggunakan pembelajaran konvensional. Kualifikasi hasil belajar dengan menggunakan model pembelajaran direct instruction berbantuan video berada pada katagori sangat tinggi, dan hasil belajar dengan menggunakan pembelajaran konvensional berada pada katagori sedang. 2) terdapat pengaruh yang signifikan model pembelajaran direct instruction berbantuan video terhadap hasil belajar rias kreatif siswa dengan siswa yang mengikuti model pembelajaran konvensional setelah kovariabel kompetensi pedagogik guru dikendalikan. 3) terdapat kontribusi yang signifikan kovariabel kompetensi pedagogik guru terhadap hasil belajar rias kreatif siswa. Berdasarkan temuan-temuan di atas dapat disimpulkan bahwa model pembelajaran direct instruction berbantuan video berpengaruh terhadap hasil belajar baik sebelum maupun setelah kovariabel kompetensi pedagogik dikendalikan.
\end{abstract}

Kata kunci: pembelajaran direct instruction berbantuan video, kompetensi pedagogik, hasil belajar

\begin{abstract}
This study aims to determine the effect of learning models directly assisted video and pedagogical competence of teachers to the creative learning result of students of class XI Beauty Beauty SMK Negeri 2 Singaraja. This research is experimental research by using quasi research design with pattern "The Posttest-Only Control Design". with a large sample of 71 people. Data collected by test. Data analysis was performed with Anakova. The result of the research shows that: 1) there is influence of creative learning result between students who follow video-assisted model directly with students who follow the conventional learning model. Student learning outcomes using video-aided learning model are higher than learning outcomes using conventional learning. Qualification of learning outcomes using video-assisted learning models is very high, and learning outcomes using conventional learning are in moderate categories. 2) there is influence of learning result of creative make-up between student which follow direct learning model assisted by videodengan student following model of conventional learning after covariabel of teacher pedagogic competence is controlled. 3) there is a covariable contribution of teacher pedagogic competence to student creative learning result. Based on the above findings it can be concluded that the video-aided instructional model has an effect on the learning outcomes before and after the covariabel of pedagogic competence is controlled.
\end{abstract}

Keywords: video-assisted learning, pedagogic competence, learning outcomes 


\section{PENDAHULUAN}

Dalam sistem penyelenggaraan pendidikan berorientasi dunia kerja di Indonesia, terdapat dua istilah pendidikan yang digunakan, yaitu: pendidikan kejuruan dan pendidikan vokasi. Pendidikan kejuruan merupakan penyelenggaraan jalur pendidikan formal yang dilaksanakan pada jenjang pendidikan tingkat menengah, yaitu pendidikan menengah kejuruan yang berbentuk Sekolah Menengah Kejuruan (SMK).

SMK N 2 Singaraja merupakan salah satu lembaga pendidikan Menengah Kejuruan Negeri yang memiliki program Keahlian Tata Kecantikan. Program Keahlian Tata Kecantikan membina dua Program Keahlian yaitu Program Keahlian Tata Kecantikan Kulit dan Tata Kecantikan Rambut. Tujuan SMK bidang Keahlian Tata Kecantikan Kulit seperti tercantum dalam GBPP SMK Bidang keahlian Tata Kecantikan (2004:2), yaitu: (1) Memasuki lapangan kerja serta dapat mengembangkan sikap professional dalam lingkup keahlian tata kecantikan; (2) Mampu memilih karir, mampu berkompetisi dan mampu mengembangkan diri dalam lingkup keahlian tata kecantikan; (3) Menjadi tenaga kerja tingkat menengah untuk mengisi kebutuhan dunia usaha dan industri pada saat ini maupun masa yang akan datang dalam lingkup keahlian tata kecantikan;(4) Menjadi warga Negara yang produktif, keratif dan adapatif.

Tujuan yang diharapkan dari standar kompetensi rias kreatif yaitu peserta didik memiliki kemampuan pengetahuan, sikap dan keterampilan dalam rias kreatif. Indikator yang diharapkan dari pembelajaran rias kreatif mencakup konsep merias kreatif, jenis-jenis merias kreatif, pengetahuan alat, dan kosmetik merias kreatif, teknik mendesain merias kreatif, dan merias kreatif. Proses kegiatan pembelajaran merias kreatif diharapkan dapat memberikan dampak positif dan memiliki nilai tambah serta memberikan perubahan pada peserta didik.

Hasil belajar merias wajah kreatif dapat dilihat dari adanya perubahan tingkah laku yang berkaitan dengan kemampuan pengetahuan, sikap dan keterampilan merias wajah kreatif. Sudjana (2009:22), mengemukakan bahwa "hasil belajar adalah kemampuankemampuan yang dimiliki siswa setelah ia menerima pengalaman belajarnya".

Hasil belajar merias wajah kreatif yang dipelajari peserta didik sesuai dari indikator mengcakup konsep merias wajah kreatif, jenis-jenis merias wajah kreatif, pengetahuan alat, dan kosmetik merias wajah kreatif, teknik mendesain merias wajah kreatif, merias wajah kreatif, diharapkan dapat membekali pesera didik untuk siap bekerja sebagai Make-up artists. Kesiapan peserta didik dapat diukur dari kemampuan yang diperoleh setelah mengikuti pembelajaran yang dapat memberikan respon terhadap suatu situasi tertentu.

Berbagai masalah pendidikan saat ini telah dihadapi, salah satu masalah dunia pendidikan adalah proses pendidikan. Dalam pelaksanaan program pendidikan di Sekolah Menengah Kejuruan (SMK) maupun lembaga pendidikan kejuruan lainnya, pembelajaran praktik memegang peran yang sangat penting. Melalui kegiatan pembelajaran praktik, siswa akan dapat menguasai keterampilan kerja secara optimal. Selain itu pendidikan kejuruan mempunyai kaitan erat dengan dunia kerja, sehingga pembelajaran dan pelatihan praktik memegang peranan kunci untuk membekali lulusannya agar mampu beradaptasi dengan lapangan kerja. Dengan begitu mereka harus dibentuk melalui serangkaian latihan atau pembelajaran dan pelatihan praktik yang hampir menyerupai dunia kerja.

Kenyataan yang terjadi pada saat ini adalah kurang maksimalnya hasil belajar peserta didik. Salah satu faktor yang menyebabkan rendahnya kualitas pembelajaran yaitu belum dimanfaatkannya sumber belajar secara maksimal, baik oleh guru maupun siswa. Sumber belajar tersebut bisa berupa perangkat pembelajaran yang merupakan perangkat yang dipergunakan dalam proses pembelajaran (Trianto, 2008:121).

Dalam proses belajar mengajar rias wajah kreatif sering dihadapkan pada kendalakendala yang dialami peserta didik. Permasalahan yang terjadi adalah kurangnya kreativitas peserta didik dalam menyampaikan ide pada proses belajar mengajar rias wajah kreatif sehingga peran guru masih terlalu besar dalam memberikan ide ide dalam pembuatan desain riasan. Kurangnya kreativitas tersebut juga dikarenakan kurangnya pengetahuan siswa dan sedikitnya minat siswa dalam membaca buku. 
Kurang kreativitasnya siswa ditunjukan dengan hasil riasan yang monoton dan seringkali sama dengan beberapa siswa yang lain. Berdasarkan hasil observasi awal khususnya mata pelajaran rias wajah kreatif pada tahun ajaran sebelumnya, ditemukan masih banyak nilai yang kurang memuaskan dan hasil praktik yang kurang rapi dikarenakan kurang pahamanya siswa terhadap materi rias wajah kreatif yang telah diberikan guru. Pada tahun ajaran sebelumnya terdapat kendala berupa, siswa masih kurang menguasai dalam praktik rias wajah kreatif panggung. Hal ini ditunjukkan dengan kurang memuaskan hasil praktik yang didapat siswa atau masih adanya nilai yang belum optimal $(<80)$.

Keberhasilan pendidikan di sekolah antara lain ditentukan oleh keberhasilan guru dalam mengajar di kelas dan mutu tenaga pendidik. Keberhasilan guru dalam mengajar di kelas, ditentukan oleh banyak faktor seperti perencanaan, persiapan mengajar, model mengajar, media mengajar, sarana dan prasarana lain yang menunjang sehingga dapat mencapai tujuan instruksional secara efektif dan efisien.

Pembelajaran adalah upaya untuk membelajarkan siswa yang secara implisit. Terlihat bahwa dalam pembelajaran ada kegiatan memilih, menetapkan dan mengembangkan metode untuk mencapai hasil yang diinginkan (Dimyati, 2006:20). Dalam proses belajar mengajar guru memiliki tanggung jawab atas keberhasilan yang dicapai siswa. Oleh karena itu guru dapat menciptakan situasi dan kondisi belajar yang efektif dengan menggunakan cara yang sesuai serta mempertimbangkan situasi dan kondisi siswa dan lingkungannya. Salah satunya dengan variasi dan inovasi.

Variasi dan inovasi dapat berupa penerapan media pembelajaran yang dapat menumbuhkan kebiasaan yang kritis serta mandiri. Media pembelajaran digunakan sebagai alat bantu mengajar dan dapat berupa seperti alat peraga,demonstrasi, permainan dan lainlain (Sudjana dan Rivai, 2002: 1).

Disini guru berperan penting dalam memilih media yang akan digunakan dalam proses belajar mengajar. Peneliti mencoba untuk menerapkan media video pada mata pelajaran rias wajah kreatif panggung. Menurut Daryanto $(2013 ; 88)$ menyatakan bahwa media video adalah segala sesuatu yang memungkinkan sinyal audio dapat dikombinasikan dengan gambar bergerak secara sekuensial. Program video dapat dimanfaatkan dalam program pembelajaran, karena dapat memberikan pengalaman yang tidak terduga kepada siswa, selain itu juga program video dapat dikombinasikan dengan animasi dan pengaturan kecepatan untuk mendemonstrasikan perubahan dari waktu ke waktu. Kemamampuan video dalam memvisualisasikan meteri terutama efektif untuk membantu anda menyampaikan materi yang bersifat dinamis. Materi yang memerlukan visualisasi yang mendemonstrasikan hal-hal seperti gerakan motorik tertentu, ekspresi wajah, maupun suasana lingkungan tertentu adalah paling baik disajikan melalui pemanfaatan teknologi video.

Sedangkan menurut Hamdani $(2011 ; 254)$ menyatakan bahwa media video sangat cocok untuk mengajarkan materi dalam ranah perilaku atau psikomotor. Pada umumnya siswa menganggap bahwa belajar melalui media video lebih mudah dibandingkan melalui teks. Video memaparkan keadaan real dari suatu proses, fenomena atau kejadian sehingga dapat memperkaya pemaparan.

Dengan media video diharapkan siswa dapat mengulang materi yang telah diajarkan baik di sekolah maupun di rumah sesuai dengan kehendaknya sehingga apabila siswa lupa atau belum mengerti mengenai teknik yang telah diajarkan, siswa dapat melihat kembali videonya di rumah. Dengan menerapkan media video ini pada mata pelajaran rias wajah kreatif diharapkan berpengaruh terhadap hasil praktik rias wajah kreatif yaitu dengan mengoptimalkan nilai yang didapat siswa (>80). Selain itu melalui media video ini siswa diharapkan dapat berkembang dan lebih menumbuhkan kretivitas siswa.

Selain penggunaan model pembelajaran direct instruction berbantuan video, faktor lain yang mempengaruhi hasil belajar siswa adalah kompetensi yang dimiliki oleh guru, khususnya kompetensi pedagogik. Menurut Saudagar dan Idrus $(2011 ; 33)$ menyatakan bahwa pedagogik adalah ilmu tentang pendidikan anak yang ruang lingkupnya terbatas pada 
interaksi edukatif antara pendidik dengan siswa, sedangkan kompetensi pedagogik adalah sejumlah kemampuan guru yang berkaitan dengan ilmu dan seni mengajar siswa.

Pedagogik adalah teori mendidik yang mempersoalkan apa dan bagaimana mendidik sebaik-baiknya. Sedangkan menurut pengertian Yunani, pedagogik adalah ilmu menuntun anak yang membicarakan masalah atau persoalan-persoalan dalam pendidikan dan kegiatan-kegiatan mendidik, antara lain seperti tujuan pendidikan, alat pendidikan, cara melaksanakan pendidikan, anak didik, pendidik dan sebagainya. Oleh sebab itu pedagogik dipandang sebagai suatu proses atau aktifitas yang bertujuan agar tingkah laku manusia mengalami perubahan. Berdasarkan Undang-Undang No. 14 tahun 2005 tentang Guru dan Dosen dijelaskan bahwa kompetensi pedagogik merupakan kemampuan seorang guru dalam mengelola proses pembelajaran yang berhubungan dengan peserta didik, meliputi pemahaman wawasan atau landasan kependidikan, pemahaman terhadap peserta didik, pengembangan kurikulum atau silabus, perancangan pembelajaran, pelaksanaan pembelajaran yang mendidik dan dialogis, pemanfaatan teknologi pembelajaran, evaluasi hasil belajar, dan pengembangan peserta didik untuk mengaktualisasikan berbagai potensi yang dimilikinya.

Menurut Saudagar dan Idrus $(2011 ; 34)$ kompetensi pedagogik yang harus dimiliki guru adalah: 1) menguasai landasan mengajar, 2) menguasai ilmu mengajar, 3) mengenal siswa, 4) menguasai teori motivasi, 5) mengenal lingkungan masyarakat, 6) menguasai penyusunan kurikulum, 7) menguasai teknik penyusunan RPP, dan 8) menguasai pengetahuan evaluasi pembelajaran, dll.

Berdasarkan penjelasan di atas, peneliti tertarik untuk meneliti tentang Pengaruh Model Pembelajaran Direct Instruction berbantuan Video dan Kompetensi Pedagogik Guru terhadap Hasil Belajar Rias Kreatif Siswa kelas XI Tata Kecantikan Kulit SMK Negeri 2 Singaraja.

\section{METODE PENELITIAN}

Penelitian ini bertujuan untuk mengetahui pengaruh model pembelajaran direct instruction berbantuan video dan kompetensi pedagogik guru terhadap hasil belajar rias kreatif siswa kelas XI Tata Kecantikan Kulit SMK Negeri 2 Singaraja. Penelitian ini menggunakan metode penelitian eksperimen. Penelitian eksperimen merupakan pendekatan penelitian kuantitatif yang penuh, dalam arti memenuhi semua persyaratan untuk menguji hubungan sebab akibat dan korelasional yang menunjukkan saling hubungan antara dua variabel atau lebih. Ciri utama dari penelitian eksperimen adalah adanya pengontrolan variabel dan pemberian perlakuan terhadap kelompok eksperimen.

Penelitian eksperimental adalah penelitian yang dengan mengadakan manipulasi terhadap subjek serta adanya kontrol (Nazir 2003:63). Penelitian eksperimen merupakan penelitian yang dimaksudkan untuk mengetahui ada tidaknya akibat dari "sesuatu" yang dikenakan pada subjek selidik (Arikunto, 2006:207). Penelitian eksperimen ada beberapa jenis. Pada penelitian ini menggunakan jenis penelitian eksperimen semu atau eksperimen kuasi, hal ini dilihat dari subjek eksperimen yang tidak dirandomisasi untuk menentukan sampel guna ditempatkan dalam kelompok eksperimen dan kelompok kontrol. Dengan pola dasar "The Posttest-Only Control-Group Desain".

Sukardi (2007:53) menyatakan bahwa populasi pada prinsipnya adalah semua anggota kelompok manusia, binatang, peristiwa atau benda yang tinggal bersama dalam satu tempat dan secara terencana menjadi target kesimpulan dari hasil suatu penelitian. Populasi dapat berupa guru, siswa, kurikulum, fasilitas, lembaga sekolah, hubungan sekolah dan masyarakat, karyawan perusahaan, jenis tanaman hutan, jenis pado, kegiatan marketing, hasil produksi dan sebagainya. Menurut Agung $(2014 ; 69)$ menyatakan populasi adalah keseluruhan objek dalam suatu penelitian.

Dari beberapa pendapat diatas dapat disimpulkan bahwa populasi adalah sejumlah siswa dalam suatu tempat yang mempunyai kualitas dan karakteristik tertentu yang ditetapkan oleh peneliti untuk dipelajari dan di tarik kesimpulan dari hasil penelitian yang 
dilakukan. Dalam penelitian ini yang menjadi populasi adalah semua siswa kelas XI Tata Kecantikan Kulit SMK Negeri 2 Singaraja yang berjumlah 71 siswa.

Sugiyono (2012:118) menyebutkan bahwa sampel adalah bagian dari jumlah dan karakteristik yang dimiliki oleh populasi. Sukardi (2003:54) menyatakan bahwa sampel adalah sebagian dari jumlah populasi yang dipilih untuk sumber data. Sedangkan menurut Agung $(2016 ; 8)$ menyatakan bahwa sampel merupakan bagian dari populasi yang secara langsung dikenai penelitian.

Dari beberapa pendapat diatas dapat dikatakan bahwa sampel merupakan bagian dari populasi yang mewakili seluruh populasi yang digunakan sebagai sumber data dalam penelitian dan sampel ini diambil dengan menggunakan teknik tertentu.

Dalam penelitian ini sampel dipilih tanpa adanya pengacakan individu, cara ini digunakan dengan mengingat dan mempertimbangkan sulitnya untuk merubah kelas yang sudah terbentuk. Kelas yang dipilih sebagaimana yang telah terbentuk tanpa adanya campur tangan peneliti. Kelas-kelas yang terpilih sebagai sampel yang mewakili populasi kemudian di bagi menjadi 2 yaitu kelas eksperimen dan kelas control. Penyajian sampel kelas dilakukan dengan menggunakan teknik random sampling.

Langkah-langkah yang ditempuh dalam pengambilan sampel penelitian ini yaitu yang pertama, melakukan uji kesetaraan terhadap seluruh kelas. Uji kesetaraan menggunakan bantuan SPSS 17.0 for windows dengan signifikansi 5\%. Jika angka signifikansi hitung kurang dari $5 \%$ atau 0,05 maka kelas tersebut tidak setara. Sedangkan jika angka signifikansi hitung lebih besar dari $5 \%$ atau 0,05 maka kelas tersebut dinyatakan setara. Menghitung uji kesetaraan diperoleh dari skor ulangan akhir semester sebelumnya / kelas sebelumnya untuk semua kelas.

Menurut Sugiyono (2012:61) menyebutkan bahwa ada empat jenis variable penelitian yaitu variabel independen (variable bebas), variabel dependen (variable terikat), variabel moderator dan variabel intervening.

Penelitian ini meyelidiki pengaruh dua variabel bebas terhadap dua variabel terikat. Variabel independent (bebas) tersebut adalah variabel yang mempengaruhi atau menjadi sebab perubahan variabel terikat. Variabel dependen (terikat) adalah variabel yang dipengaruhi atau yang menjadi akibat karena adanya variabel bebas. Kedua variabel bebas tersebut adalah yakni variabel model pembelajaran direct instruction berbantuan video dan model pembelajaran konvensional. Model pembelajaran direct instruction berbantuan video diberikan pada kelompok eksperimen dan model pembelajaran konvensional diberikan pada kelompok kontrol. Sedangkan variabel terikat yang diteliti dalam penelitian ini adalah kompetensi pedagogik dan hasil belajar. Kompetensi pedagogik guru adalah skor yang diperoleh jawaban kuesioner guru. Sedangkan hasil belajar di dapatkan dari hasil tes pada akhir penelitian.

Data yang dikumpulkan dalam penelitian ini meliputi: 1) kompetensi pedagogik guruguru di SMKN 2 Singaraja, 2) hasil belajar siswa di SMKN 2 Singaraja, dan 3) respon guru terhadap penerapan model pembelajaran direct instruction berbantuan video.

Validasi isi instrumen dilakukan dengan meminta bantuan pada dua orang pakar (Expert Judges) untuk menilai kelayakan masing-masing item yang sudah disusun oleh peneliti. Validitas dalam penelitian ini ditinjau dari dua segi yaitu validitas isi dan validitas butir. Untuk memenuhi validitas isi ditempuh langkah sebagai berikut: pertama, membuat kisi-kisi terlebih dahulu. Kedua, instrument dikonsultasikan kepada pakar yang berfungsi sebagai Judges untuk menilai kuesioner berdasarkan dasar teori yang ada dan indikatorindikatornya.

Setelah dibuangnya butir-butir yang tidak layak, serta dilakukannnya revisi terhadap butir-butir yang layak sesuai saran dari Judges, maka butir yang tidak layak tidak ada lagi dalam instrumen pasca uji oleh Expert Judges. Karena itu, besaran koefisien validitas isi instrumen pascauji Expert Judges adalah sesuai dengan rumus Gregory, yaitu tabulasi silang $2 \times 2$ yang terbagi menjadi sel $A$, sel $B$, sel $C$, dan Sel D. 
Pengukuran validitas instrumen tiap butir dalam penelitian ini, digunakan analisis item, yaitu dengan mengkorelasikan skor tiap butir dengan skor total yang merupakan jumlah skor tiap butir soal. Penentuan validitas butir soal digunakan rumus korelasi product moment. Valid tidaknya suatu item instrument dapat diketahui dengan membandingkan nilai koefisien korelasi product moment $\left(\mathrm{r}_{\mathrm{xy}}\right)$ hasil perhitungan dengan nilai koefisien korelasi yang terdapat pada $r_{\text {tabel }}$ dengan taraf signifikansi $5 \%$. Apabila $r_{x y}$ positif dan lebih besar daripada $r_{\text {tabel, }}$ maka item tersebut dinyatakan valid dan jika $r_{x y}$ lebih kecil dari $r_{\text {tabel }}$ maka butir soal dinyatakan gugur (tidak valid).

Uji realibilitas instrumen dilakukan secara internal konsistensi yakni mencoba instrumen sekali saja kemudian butir yang telah dinyatakan valid berdasarkan uji validitas dengan Alpha Cronbach. Realibilitas instrumen yang berbentuk angket dan rating scale diuji dengan rumus Alpha Cronbach (Koyan, 2011: 135).

Pendeskripsian data hasil belajar siswa dan kompetensi pedagogik guru berdasarkan tendensi data, meliputi mean, median, modus, standar deviasi, varians, rentangan, skor maksimum, dan skor minimum. Sebaran data hasil belajar dan kompetensi pedagogik guru disajikan dalam bentuk tabel dan gambar diagram untuk masing-masing pembelajaran konvensional.

Kualifikasi data hasil belajar dan kompetensi pedagogik guru, juga menggunakan analisis univariant. Analisis ini didasarkan pada skor rerata ideal (Mi) dan simpangan baku ideal (SDi). Kriteria kualifikasi perubahan data hasil belajar dan kompetensi pedagogik guru digolongkan menjadi lima. Untuk analisis kovarian diperlukan beberapa persyaratan analisis adalah uji normalitas sebaran data, uji homogenitas varians, dan uji linieritas.

Analisis data yang digunakan adalah Anakova. Untuk menguji hipotesis 1, digunakan analisis varians satu jalur. Untuk menguji hipotesis 2, digunakan analisis kovarian satu jalur dengan kovariabel kompetensi pedagogik. Untuk menguji hipotesis 3 , yaitu mengetahui hubungan kovariabel kompetensi pedagogik guru terhadap hasil belajar rias kreatif siswa digunakan korelasi product moment.

\section{HASIL PENELITIAN DAN PEMBAHASAN}

1. terdapat pengaruh yang signifikan model pembelajaran direct instruction berbantuan video terhadap hasil belajar rias kreatif siswa dengan siswa yang mengikuti model pembelajaran konvensional

Analisis deskriptif tentang kompetensi pedagogik dengan menggunakan model pembelajaran direct instruction berbantuan video menunjukkan bahwa rata-rata skor kompetensi pedagogik dengan menggunakan model pembelajaran direct instruction berbantuan video adalah 155,46 lebih besar dari rata-rata kompetensi pedagogik dengan menggunakan pembelajaran konvensional yaitu sebesar 134,21. Begitupula dengan ratarata skor hasil belajar dengan menggunakan model pembelajaran direct instruction berbantuan video yaitu sebesar 56,46 lebih besar dari rata-rata hasil belajar dengan menggunakan pembelajaran konvensional yaitu sebesar 36,18. Oleh karena itu dapat disimpulkan bahwa kompetensi pedagogik dengan menggunakan model pembelajaran direct instruction berbantuan video lebih baik daripada kompetensi pedagogik dengan menggunakan pembelajaran konvensional dan hasil belajar dengan menggunakan model pembelajaran direct instruction berbantuan video lebih baik daripada hasil belajar dengan menggunakan pembelajaran konvensional.

Hasil uji hipotesis pertama telah berhasil menolak hipotesis nol yang menyatakan bahwa tidak terdapat perbedaan hasil belajar rias kreatif antara siswa yang menggikuti model pembelajaran direct instruction berbantuan videodengan siswa yang mengikuti model pembelajaran konvensional dengan skor $F A_{\text {hitung }}=254,001$, dan $p<0,05$. Dari rata-rata skor hasil belajar dengan menggunakan model pembelajaran direct instruction berbantuan video $=56,46$ dan rata-rata skor hasil belajar dengan menggunakan pembelajaran konvensional 36,18. Sehingga secara keseluruhan, hasil belajar dengan menggunakan model pembelajaran direct instruction berbantuan video lebih tinggi daripada hasil belajar dengan 
menggunakan pembelajaran konvensional. Dari hasil uji hipotesis tersebut mengisyaratkan bahwa model pembelajaran direct instruction berbantuan video lebih unggul dalam meningkatkan hasil belajar.

Hasil penelitian tersebut sejalan dengan penelitian yang dilakukan Lestari (2013) dengan judul "Pengaruh Penerapan Media Video Terhadap Hasil Belajar Siswa pada Sub Kompetensi Merias Wajah Panggung Kelas X Tata Kecantikan Kulit Di SMKN 2 Boyolangu Tulungagung". Hasil penelitian ini adalah hasil belajar siswa dan respon siswa. Hasil belajar siswa menunjukkan rata - rata nilai post-test 82,0806 lebih baik dari pre-test 64,1968 . Hasil Respon siswa menunjukkan total hasil rating media video adalah $80,64 \%$ baik yang artinya terdapat pengaruh penggunaan media video terhadap hasil belajar siswa pada sub kompetensi rias wajah panggung kelas $X$ tata kecantikan kulit di SMKN 2 Boyolangu Tulungagung.

Model pembelajaran langsung atau Direct Instruction, juga dikenal dengan istilah strategi belajar ekspositori dan whole class teaching. Pembelajaran langsung merupakan suatu model pembelajaran yang terdiri dari penjelasan guru mengenai konsep atau keterampilan baru terhadap siswa.Model pembelajaran ini dirancang khusus untuk menunjang proses belajar siswa yang berkaitan dengan pengetahuan deklaratif dan pengetahuan prosedural yang terstruktur dengan baik, dapat diajarkan dengan pola kegiatan yang bertahap selangkah demi selangkah.

Pengajaran direct instruction adalah model berpusat pada guru yang memiliki lima langkah: menetapkan tujuan, penjelasan dan/atau demonstrasi, panduan praktek, umpan balik, dan perluasan praktek. Pelajaran dalam pengajaran direct instruction memerlukan perencanaan yang hati-hati oleh guru dan lingkungan belajar yang menyenangkan dan berorientasi tugas.

Pembelajaran konvensional mengacu pada psikologi behavioristik, di mana guru berperan sebagai pusat informasi (teacher centered). Siswa dipandang sebagai komponen pasif dalam pembelajaran, memerlukan motivasi luar dan dipengaruhi oleh reinforcement. Proses pembelajaran secara konvensional menempatkan guru sebagai sumber belajar yang mengajarkan pengetahuan dan keterampilan kepada siswa.

Pendekatan pembelajaran konvensional yang dilakukan guru adalah memberikan hafalan kepada siswa. Kegiatan pembelajaran dengan pembelajaran konvensional paling efisien dalam mengajar karena bersifat hafalan (ingatan). Keadaan ini menunjukan bahwa ceramah yang dilakukan guru mendominasi kegiatan belajar mengajar yang menekankan kegiatan hafalan tersebut. Dalam hal ini siswa merupakan komponen yang pasif karena guru mendominasi secara penuh dalam pelaksanaan pembelajaran. Ceramah merupakan salah satu cara penyampaian informasi dengan lisan dari seseorang (guru) kepada sejumlah pendengar (siswa) di suatu ruangan.

Berdasarkan perbedaan antara model pembelajaran direct instruction berbantuan video dengan model pembelajaran konvensional maka dapat dikatakan akan terjadi perbedaan hasil belajar antara siswa yang belajar mengunakan model pembelajaran direct instruction berbantuan video dengan siswa yang belajar menggunakan model pembelajaran konvensional.

\section{2. terdapat pengaruh yang signifikan model pembelajaran direct instruction berbantuan video terhadap hasil belajar rias kreatif siswa dengan siswa yang mengikuti model pembelajaran konvensional setelah kovariabel kompetensi pedagogik dikendalikan}

Kedua, terdapat perbedaan hasil belajar rias kreatif antara siswa yang menggikuti model pembelajaran direct instruction berbantuan video dengan siswa yang mengikuti model pembelajaran konvensional setelah kovariabel kompetensi pedagogik guru dikendalikan. Hasil uji hipotesis kedua telah berhasil menolak hipotesis nol yang menyatakan tidak terdapat pengaruh yang signifikan antara model pembelajaran direct instruction berbantuan video terhadap hasil belajar pengantar pariwisata siswa kelas XI jurusan perhotelan di SMK 
Negeri 2 Singaraja setelah kovariabel kompetensi pedagogik guru dikendalikan. Hal ini tampak dengan melihat harga $F_{\text {hitung }}$ sebesar 6,788 $>F_{\text {tabel }}=4,00$ nilai signifikansi lebih kecil daripada 0,05 yaitu sebesar 0,011 . Hal ini berarti hipotesis nol $\left(\mathrm{H}_{0}\right)$ di tolak dan hipotesis 1 $\left(\mathrm{H}_{1}\right)$ yang menyatakan bahwa "terdapat perbedaan hasil belajar rias kreatif antara siswa yang menggikuti model pembelajaran direct instruction berbantuan video dengan siswa yang mengikuti model pembelajaran konvensional setelah kovariabel kompetensi pedagogik guru dikendalikan", diterima.

Hasil ini sekaligus membuktikan bahwa hasil belajar siswa dengan menggunakan model pembelajaran direct instruction berbantuan video memang lebih baik daripada hasil belajar siswa yang mengikuti pembelajaran konvensional sekalipun ditinjau dari kompetensi pedagogiknya. Temuan dalam penelitian ini juga sejalan dengan hasil penelitian yang dilakukan oleh Sukmana (2015) yang berjudul Pengaruh Model Pembelajaran Langsung (Direct Instruction) Disertai Media Gambar Terhadap Hasil Belajar Biologi Siswa Kelas VII SMP Negeri 1 Tambusai Utara. Dalam penelitiannya disimpulkan bahwa terdapat pengaruh model pembelajaran langsung (Direct Instruction) disertai media gambar terhadap hasil belajar siswa kelas VII SMP Negeri 1 Tambusai Utara Tahun Pembelajaran 2014/2015. Dari hasil pengujian hipotesis diperoleh $\mathrm{t}$ hitung $=5,14$ sedangkan $\mathrm{t}$ tabel untuk taraf kesalahan $5 \%$ dengan $n=69$ diperoleh $t$ tabel $=1,67$ sehingga $t$ hitung $>t$ tabel $(5,14>$ $1,67)$.

Kompetensi pedagogik adalah kemampuan mengelola pembelajaran peserta didik.Wawasan tentang Kompetensi pedagogik mencakup pemahaman dan pengembangan potensi peserta didik, perencanaan dan pelaksanaan pembelajaran, serta system evaluasi pembelajaran, juga harus menguasai "ilmu pendidikan" ilmu pendidikan merupakan ilmu dasar untuk memahami kegiatan yang disebut pendidikan atau kegiatan mendidik. IImu pendidikan dapat diartikan sebagai suatu ilmu yang memberikan uraian yang lengkap, sistematis dan metodis tentang masalah-masalah yang ada kaitannya dengan proses pendidikan atau kegiatan mendidik. Maka berarti ilmu pendidikn itu suatu ilmu pengetahuan yang ilmiah yang tidak usah diragukan lagi kebenarannya karena sudah memiiki kriteria persyaratan ilmu pengetahuan yang ilmiah yaitu memilih objek, metode dan sistematika yang jelas dan pasti.

Kompetensi guru merupakan seperangkat pengetahuan, keterampilan, dan perilaku yang harus dimiliki, dihayati, dikuasai, dan diaktualisasikan oleh Guru dalam melaksanakan tugas keprofesionalan.

Salah satu karakteristik dari suatu model pembelajaran adalah adanya sintaks/tahapan pembelajaran. Selain harus memperhatikan sintaks, guru yang akan menggunakan pengajaran langsung juga harus memperhatikan variabel-variabel lingkungan lain, yaitu fokus akademik, arahan dan kontrol guru, harapan yang tinggi untuk kemajuan siswa, waktu dan dampak dari pembelajaran.Joyce and Weil berpendapat beberapa keunggulan terpenting dari pembelajaran langsung adalah adanya fokus akademik merupakan prioritas pemilihan tugas-tugas yang harus dilakukan siswa selama pembelajaran, aktivitas akademik harus ditekankan.

Pengarahan dan kontrol guru terjadi ketika memilih tugas-tugas siswa dan melaksanakan pembelajaran, menentukan kelompok, berperan sebagai sumber belajar selama pembelajaran dan meminimalkan kegiatan non akademik. Kegiatan pembelajaran diarahkan pada pencapaian tujuan sehingga guru memiliki harapan yang tinggi terhadap tugas-tugas yang harus dilaksanakan oleh siswa.

Berdasarkan pemaparan diatas dapat dikatakan terdapat perbedaan pengaruh model pembelajaran direct instruction berbantuan video dengan model pembelajaran konvensional setelah kovariabel kompetensi pedagogik dikendalikan.

\section{3. terdapat kontribusi yang signifikan kovariabel kompetensi pedagogik guru terhadap hasil belajar rias kreatif siswa.}


Ketiga, terdapat kontribusi kompetensi pedagogik terhadap hasil belajar. Kompetensi pedagogik dalam penelitian ini memberikan kontribusi positif terhadap hasil belajar, walaupun tetap dipengaruhi oleh faktor-faktor yang lainnya. Kontribusi kovaribel kompetensi pedagogik terhadap hasil belajar, ditunjukan dengan melihat harga $r_{\text {hitung }}$ sebesar 0,933 yang lebih besar dari pada $r$ tabel $(0,215)$. Keselarasan $r^{2}$ sebesar 0,870 yang berarti $87,0 \%$ perubahan pada hasil belajar dapat diterangkan oleh kompetensi pedagogik. Dengan demikian, kompetensi pedagogik memang berkontribusi positif terhadap hasil belajar.

Hasil ini sejalan dengan penelitian yang dilakukan oleh Indra (2016) yang berjudul"Pengaruh Kompetensi Pedagogik dan Kompetensi Profesional Guru PAI Terhadap Hasil belajar PAI pada Siswa Di SMK FarmakoMedika Plus Caringin - Bogor". Hasil perhitungan koefisien determinasiadalah $R^{2}=0,119=11,9 \%$. Hasil ini menunjukkan bahwa variabel bebas kompetensi pedagogic guru dan kompetensi professional secara bersamasama mempengaruhi variabel dependen hasil belajar siswa sebesar $11,9 \%$ dan sisanya $88,1 \%$ dipengaruhi oleh sebab lain yang tidak masuk dalam penelitian ini.Hasil penelitian ini membuktikan bahwa terdapat pengaruh yang positif dancukupsignifikan dari kompetensi pedagogik dan kompetensi professional guru PAI terhadap hasil belajar pada siswa di SMK Farmako Medika Plus Caringin Bogor, sehingga semakin baik kompetensi pedagogik dan kompetensi professional gurumaka akan semakin baik pula hasil belajar siswa.

Kompetensi pedagogik mreliputi: (1) Memahami peserta didik secara mendalam, (2) Merancang pembelajaran, termasuk memahami ladasan pendidikan untuk kepentingan pembelajaran, (3) Meleksanakan pembelajaran, (4) Merancang dan melaksanakan evaluasi pembelajaran, (5) Mengembangkan peserta didik untuk mengaktualisasikan berbagai potensinya.

Dalam UU No. 14 tahun 2005 tentang guru dan dosen dikemukakan kompetensi pedagogik adalah "kemampuan mengelola pembelajaran peserta didik" Depdiknas (2004:9) menyebut kopetensi ini dengan "kompetensi pengelolaan pembelajaran". Kompetensi ini dapat dilihat dari kemampuan merencanakan program belajar mengajar, kemampuan melaksanakan interaksi atau mengelola proses belajar mengajar, dan kemampuan melakukan penilaian.

Kemampuan mengelola pembelajaran, meliputi a) Pemahaman peserta didik, b) Perancangan, pelaksanaan dan evaluasi kualitas pengelolaan pembelajaran, dan c) pengembangan peserta didik untuk mengaktualisaikan berbagai potensi yang dimilikinya.

Berdasarkan aspek-aspek yang terdapat pada kompetensi pedagogik guru, dan hasil penelitian yang dilakukan maka dapat dikatakan terdapat kontribusi kovariabel kompetensi pedagogik guru terhadap hasil belajar rias kreatif siswa.

\section{PENUTUP}

Berdasarkan hasil pengujian hipotesis dan pembahasan, dapat ditarik simpulan sebagai berikut.

Pertama, terdapat pengaruh hasil belajar rias kreatif antara siswa yang menggikuti model pembelajaran direct instruction berbantuan video dengan siswa yang mengikuti model pembelajaran konvensional. Hasil belajar siswa dengan menggunakan model pembelajaran direct instruction berbantuan video lebih tinggi dari pada hasil belajar menggunakan pembelajaran konvensional. Kualifikasi hasil belajar dengan menggunakan model pembelajaran direct instruction berbantuan video berada pada katagori sangat tinggi, dan hasil belajar dengan menggunakan pembelajaran konvensional berada pada katagori sedang.

Kedua, terdapat pengaruh hasil belajar rias kreatif antara siswa yang menggikuti model pembelajaran direct instruction berbantuan videodengan siswa yang mengikuti model pembelajaran konvensional setelah kovariabel kompetensi pedagogik guru dikendalikan.

Ketiga, terdapat kontribusi kovariabel kompetensi pedagogik guru terhadap hasil belajar rias kreatif siswa. Berdasarkan temuan-temuan di atas dapat disimpulkan bahwa 
model pembelajaran direct instruction berbantuan video berpengaruh terhadap hasil belajar baik sebelum maupun setelah kovariabel kompetensi pedagogik dikendalikan.

Berdasarkan kesimpulan dan implikasi penelitian yang telah dipaparkan di atas, maka dapat disarankan beberapa hal yaitu sebagai berikut.

Kepada guru diharapkan agar menerapkan model pembelajaran direct instruction berbantuan video dalam proses pembelajaran, karena sudah terbukti dapat meningkatkan hasil belajar siswa.

Melihat keterbatasan waktu dan pokok bahasan yang digunakan dalam penelitian ini, maka disarankan penelitian lain agar melaksanakan penelitian sejenis dengan pemilihan variabel yang berbeda dan waktu yang lebih lama untuk mendap atkan gambaran yang lebih meyakinkan mengenai pengaruh model pembelajaran direct instruction berbantuan video terhadap hasil belajar ditinjau dari kompetensi pedagogik guru. Dalam penelitian ini variabelnya juga dapat dikembangkan sehingga nantinya dapat memperoleh hasil yang lebih baik.

\section{DAFTAR RUJUKAN}

Agung, Anak Agung Gede. 2014. Metodologi Penelitian Pendidikan. Malang: Aditya Media Publishing.

Agung, Anak Agung Gede. 2016. Statistika Dasar untuk Pendidikan. Yogyakarta; Depublish.

Bastian, Indra. 2007. Sistem Akuntansi Sektor Publik. Jakarta: Salemba Empat.

Daryanto. 2013. Strategi dan tahapan mengajar (bekal keterampilan dasar bagi guru). Bandung: CV Yrama Widya.

Departemen Pendidikan Nasional, 2005. Undang-Undang Nomor 14 Tahun 2005, Tentang Guru dan Dosen, Jakarta: Depdiknas.

Dimyati dan Mudjiono. 2006. Belajar dan Pembelajaran. Jakarta: PT Rineka Cipta

Hamdani. 2011. Strategi Belajar Mengajar. Bandung : Pustaka Setia

Koyan, I Wayan. 2011. Statistik Teknik Analisis Data Kuantitatif. Singaraja: Universitas Pendidikan Ganesha Press

Lestari, Riesma Cyndai. 2013. Pengaruh Penerapan Media Video Terhadap Hasil Belajar Siswa pada Sub Kompetensi Merias Wajah Panggung Kelas X Tata Kecantikan Kulit Di SMKN 2 Boyolangu Tulungagung. e-Journal. Pendidikan Tata Rias, Fakultas Teknik, Universitas Negeri Surabaya Volume 02 Nomor 03 Tahun 2013, hal 1-7.

Moch.Nazir. 2003. Metode Penelitian. Salemba Empat. Jakarta.

Nana Sudjana. 2009. Penilaian Hasil Proses Belajar Mengajar. Bandung: PT Remaja Rosdakarya.

Saudagar, Fachruddin dan Idrus, Ali. 2011. Pengembangan Profesionalitas Guru. Jakarta: Gaung Persada

Sudjana dan Rivai. 2002. Media Pendidikan. Jakarta: Balai Pustaka.

Sugiyono. 2012. Metode Penelitian Kuantitatif Kualitatif dan R\&B. Bandung: Alfabeta.

Sukardi, 2007. Metodologi Penelitian Pendidikan. Jakarta: PT.Bumi Aksara 
JAPI, Vol. 10 No. 1, Bulan April Tahun 2019

ISSN: 2613-9561

Sukmana, Eis. 2015. Pengaruh Model Pembelajaran Langsung (Direct Instruction) Disertai Media Gambar Terhadap Hasil Belajar Biologi Siswa Kelas VII SMP Negeri 1 Tambusai Utara. e-Jurnal Fakultas Keguruan dan IImu Pendidikan Universitas Pasir Pengaraian.

Trianto. 2008. Mendesain Pembelajaran Kontekstual (Contextual Teaching and Learning) di Kelas. Surabaya: Cerdas Pustaka. 